\title{
Pengembangan potensi lokal ikan menjadi nugget dan abon ikan untuk meningkatkan kesejahteraan masyarakat dan menurunkan angka kejadian stunting di Kanigoro, Saptosari, Gunungkidul
}

\author{
Raden Roro Dewi Ngaisyah, 1," Andre Kusuma Adiputra ${ }^{2}$ \\ ${ }^{1}$ Program Studi Ilmu Gizi, Universitas Respati Yogyakarta, Yogyakarta, Indonesia \\ ${ }^{2}$ Fakultas IImu Sosial dan Ekonomi, Universitas Respati Yogyakarta, Yogyakarta, Indonesia
}

Submitted: 13 Juli 2018 Revised: 15 Oktober 2018 Accepted: 16 November 2018

\begin{abstract}
ABSTRAK Desa Kanigoro memiliki sumber daya alam ikan yang berpotensi untuk dikembangkan. Selain itu, karena lokasinya yang berada di pesisir pantai Desa Kanigoro dapat dikembangkan menjadi pusat industri rumahan kuliner berbahan dasar ikan lokal, misalnya nugget dan abon, yang merupakan sumber protein hewani. Sayangnya, angka kejadian stunting di Desa Kanigoro cukup tinggi, yaitu sebesar $48,2 \%$, padahal makanan alternatif berbahan dasar ikan lokal dapat dijadikan sumber pangan dalam rangka mengatasi masalah stunting. Kami bersama mitra, yaitu tim penggerak pemberdayaan kesejahteraan keluarga (PKK), mengembangkan pengolahan ikan lokal menjadi nugget dan abon, serta memasarkannya untuk meningkatkan status ekonomi keluarga di Desa Kanigoro. Selain itu, kami juga melakukan upaya peningkatan kapasitas kader pos pelayanan terpadu (posyandu) untuk melakukan penyuluhan agar konsumsi ikan dan olahannya berupa nugget dan abon meningkat. Kegiatan dilakukan dengan pendekatan berbasis kelompok masyarakat sebagai mitra. Mitra tersebut adalah kader posyandu dan tim penggerak PKK Desa Kanigoro. Kegiatan diawali dengan melakukan sosialisasi kegiatan dan perijinan, dilanjutkan dengan kegiatan musyawarah desa untuk membangun partisipasi dan mengetahui kebutuhan dasar masyarakat. Kemudian, mitra diberi pelatihan dan pendampingan. Sentra produksi di Desa Kanigoro mampu memproduksi nugget dan abon, meningkatkan kapasitas produksi, dengan tetap menjaga komposisi dan nilai gizi produk. Selain itu, produk nugget dan abon rasanya enak, telah memenuhi syarat kesehatan, dan nilai gizi produk juga sudah dicantumkan pada kemasan yang menarik. Kader posyandu mampu melaksanakan perannya dalam melakukan penyuluhan pola konsumsi makanan dan melakukan monitoring stunting pada anak berusia di bawah lima tahun (balita) dengan cakupan pengukuran tinggi badan (TB)/ panjang badan (PB) balita sebesar $100 \%$. Tim penggerak PKK di Desa Kanigoro mampu mengembangkan potensi pangan lokal, yaitu ikan, menjadi produk nugget dan abon yang enak, sehat, dan dikemas dalam kemasan menarik. Kader posyandu berhasil meningkatkan pengetahuan dan konsumsi ikan, serta mampu melakukan monitoring stunting pada balita. Untuk menjaga keberlanjutan konsumsi ikan pada balita sebaiknya terus dilakukan penyuluhan mengenai pola konsumsi sehat oleh kader posyandu.
\end{abstract}

KATA KUNCI nugget ikan; abon ikan; pangan lokal; tim penggerak PKK; kader posyandu

ABSTRACT Kanigoro Village is blessed abundantly with great potentcy for fish resources development. Its strategic location by the seashore also poses an opportunity for Kanigoro to become a center for local home-based culinary industries focusing on local fish, such as fish nuggets and floss, which are rich sources of animal protein. Despite the plentiful local protein sources, a high prevalence of stunting continues to plague Kanigoro Village, reaching up to $48.2 \%$. Developing fish-based culinary industries may become a

\footnotetext{
*Corresponding author: Rr. Dewi Ngaisyah

Program Studi IImu Gizi, Universitas Respati Yogyakarta, Jl. Laksda Adisucipto No.31, Ambarukmo, Caturtunggal, Depok, Sleman, Daerah Istimewa Yogyakarta 55281, Indonesia

E-mail: dewi.fikes@yahoo.co.id
} 
means to reduce the stunting rates as well as to improve the economic status of the villagers. This project aimed to develop the fish-based local food processing into nuggets and floss to improve family economies and nutritional status in Kanigoro Village through a community-based approach. It began with the sharing of the project plan to gain support from the community. The team collaborated with local Kanigoro organizations, namely posyandu cadres and women's group. The training was given to the women's group on marketing, such as providing nutritional information on the packages, developing attractive packaging, and introducing marketing niches. Posyandu cadres were trained to motivate the villagers to increase fish consumption. After the training, the groups conducted meetings with the local women under the supervision of the team. In the meeting sessions, they encouraged villagers to eat more fish. Through the training, the local women acquired new knowledge on product enhancement, starting from improved processing hygiene, upgraded packaging, provision of nutritional information, and innovative marketing ventures. In the gatherings, posyandu cadres were able to deliver motivation to augment fish consumption. They could measure the height and weight of children under five correctly, enabling them to identify children with stunting. The knowledge and skills acquired from this project will equip the local villagers to prevent and reduce stunting prevalence in Kanigoro Village.

KEYWORDS fish nugget; fish floss; local food; PKK agents; posyandu cadres

\section{Pendahuluan}

Desa Kanigoro terletak di Kecamatan Saptosari, Kabupaten Gunungkidul, Daerah Istimewa Yogyakarta dengan luas wilayah $2.515 \mathrm{Ha}$. Desa Kanigoro memiliki 10 pedukuhan, dengan jumlah penduduk 6.760 orang, terdiri dari laki-laki sebanyak 3.352 orang dan perempuan sebanyak 3.408 orang. Mata pencaharian penduduk Desa Kanigoro sebagian besar adalah nelayan. Penduduk lainnya bekerja sebagai petani, buruh, wiraswasta, dan karyawan swasta maupun pemerintah [pegawai negeri sipil (PNS), anggota Tentara Nasional Indonesia (TNI), atau anggota Kepolisian Negara Republik Indonesia (POLRI)]. ${ }^{1}$

Desa Kanigoro memiliki sumber daya alam yang sangat potensial untuk dikembangkan. Desa Kanigoro terletak di pesisir pantai dengan penduduk yang sebagian besar bekerja sebagai nelayan sehingga memiliki potensi sumber daya ikan untuk dikembangkan. Desa Kanigoro memiliki beberapa pantai yang sangat potensial untuk dijadikan sebagai tempat wisata, di antaranya Pantai Ngrenehan, Pantai Ngobaran, dan Pantai Nguyahan. Lokasi Desa Kanigoro yang berada di pesisir pantai sangat cocok dikembangkan menjadi daerah wisata dengan industri rumahan kuliner dari bahan ikan lokal, misalnya nugget dan abon.
Pengolahan ikan dapat menjadi nilai tambah Desa Kanigoro dalam meningkatkan kesejahteraan dan kesehatan warganya, terutama dalam menyediakan lapangan pekerjaan, meningkatkan pendapatan nelayan, dan menyediakan sumber protein hewani. Namun demikian, masih didapatkan kendala dalam hal pemasaran, yaitu rendahnya penerimaan pasar terhadap produk karena makanan hasil olahan dari ikan belum memenuhi standar, baik dari segi pengemasan, rasa, keberadaan merek, penampilan, dan kesehatan.

Keberadaan Tim Penggerak Pemberdayaan Kesejahteraan Keluarga (PKK) Desa Kanigoro sebagai motor penggerak pemberdayaan wanita khusunya ibu-ibu rumah tangga berperan penting. Warga masyarakat berinisiatif memanfaatkan ikan menjadi makanan olahan dalam bentuk nugget dan abon ikan. Sebelumnya, Tim Penggerak PKK Desa Kanigoro pernah mendapatkan pelatihan pembuatan nugget dan abon ikan, serta sumbangan alat untuk mengolah ikan menjadi nugget dan abon, seperti alat pengering abon, freezer, dan meja pemotong nugget, dari Dinas Pertanian dan Kelautan. Ibu-ibu PKK menjadi mampu memproduksi nugget dan abon ikan dalam jumlah yang lebih banyak secara mandiri. Produk 
nugget dan abon ikan dapat menjadi sumber protein hewani bagi masyarakat. Namun demikian, masih perlu dilakukan perbaikan kualitas produk agar nugget dan abon ikan yang dihasilkan lebih bisa diterima oleh masyarakat. Produk nugget dan abon ikan juga perlu dipopulerkan, khususnya pada ibu-ibu dengan anak berusia di bawah lima tahun (balita), dengan jalan menyelenggarakan penyuluhan pola konsumsi sehat oleh kader pos pelayanan terpadu (posyandu). Konsumsi protein yang cukup dapat menjadi salah satu jalan untuk menurunkan kejadian stunting. ${ }^{2}$

Posyandu balita di Desa Kanigoro berjumlah 10 dan dikelola oleh 50 kader. Semua posyandu di Desa Kanigoro dikategorikan sebagai posyandu madya, di mana kegiatan posyandu dilaksanakan lebih dari 8 kali per tahun dan jumlah kader pada setiap posyandu sebanyak 5 orang. Meskipun demikian, kejadian stunting di Desa Kanigoro dari tahun ke tahun masih cukup tinggi, yaitu sebesar $48,2 \%{ }^{3}$ Angka kejadian stunting di Desa Kanigoro telah melebihi prevalensi kejadian stunting pada tingkat nasional yang sebesar $37,2 \%{ }^{4}$ Upaya penanggulangan masalah stunting berbasis pangan terus dilakukan untuk menurunkan angka kejadian anak stunting. Ditinjau dari perspektif ketahanan pangan yang berkelanjutan, makanan alternatif berbasis bahan lokal misalnya ikan dapat menjadi sumber pangan daerah dan dapat terus ditingkatkan potensinya dalam rangka percepatan pemberantasan stunting. ${ }^{5}$

Sampai saat ini, kader posyandu di Desa Kanigoro berperan aktif dalam meningkatkan status kesehatan balita melalui kegiatan rutin 5 meja di posyandu. Tim pengabdian melakukan pendampingan dan memotivasi kader untuk senantiasa melakukan upaya-upaya penurunan angka kejadian stunting melalui perbaikan pola konsumsi. Upaya yang dilakukan adalah penyuluhan mengenai pola makan sehat dan pemantauan status gizi. Semua kegiatan posyandu sangat bergantung pada partisipasi kader posyandu. Karena pentingnya peran kader posyandu, peningkatan peran dan kapasitas kader posyandu dalam promosi kesehatan perlu dilaksanakan.
Selama ini, Pemerintah Desa Kanigoro secara rutin memfasilitasi pertemuan paguyuban kader posyandu setiap bulan.

Kegiatan yang dilaksanakan pada pertemuan rutin paguyuban tersebut adalah penyampaian pelaporan hasil penimbangan balita dan pemberian materi untuk menambah wawasan keilmuan para kader oleh petugas kesehatan dari pusat kesehatan masyarakat (puskesmas) maupun dinas terkait. Kerjasama dengan berbagai pihak juga telah diupayakan untuk meningkatkan kapasitas kader posyandu, antara lain diwujudkan dalam kegiatan pelatihan kader posyandu oleh Program Studi Strata Satu (S-1) Ilmu Gizi, Universitas Respati, Yogyakarta dan Lembaga Swadaya Masyarakat (LSM) Cita Sehat.

Pemerintah Desa Kanigoro menyadari bahwa peran serta kader dalam upaya meningkatkan derajat kesehatan yang terukur oleh indikatorindikator kesehatan merupakan hal yang sangat penting guna mendukung program pemerintah melalui kegiatan pemberdayaan masyarakat berupa revitalisasi posyandu. Kader sebagai tenaga sukarela yang dipilih oleh dan dari masyarakat bertugas untuk memberdayakan masyarakat. Direktorat Bina Peran Serta Masyarakat Kementerian Kesehatan Republik Indonesia memberikan definisi bahwa kader adalah warga masyarakat setempat yang dipilih dan ditinjau oleh masyarakat dan dapat bekerja secara sukarela, ${ }^{6}$ begitu juga kader posyandu di Desa Kanigoro yang sebagian besar adalah ibu-ibu rumah tangga. Mereka dengan sukarela meluangkan waktu, tenaga, dan pikiran untuk mengelola posyandu. Kader posyandu adalah orang yang mempunyai tugas untuk melaksanakan program posyandu. Program posyandu untuk mewujudkan masyarakat sehat antara lain adalah monitoring status stunting anak balita dan penyuluhan pola konsumsi sehat.

Pengabdian kepada masyarakat dan penelitian ini bertujuan untuk membuat nugget dan abon ikan yang memenuhi standar kesehatan dan layak untuk dipasarkan. Selain itu dilakukan juga penyuluhan pola konsumsi sehat kepada masyarakat agar tertanam kesadaran untuk mengkonsumsi 
lebih banyak protein hewani. Kegiatan tersebut diharapkan dapat memberdayakan masyarakat dalam mengatasi permasalahan stunting.

\section{Metode}

Kegiatan dilakukan dengan pendekatan berbasis kelompok masyarakat, bersama dengan dua mitra di Desa Kanigoro, yaitu kader posyandu dan tim penggerak PKK. Kegiatan diawali dengan melakukan sosialisasi dan perizinan. Sosialisasi melibatkan Pemerintah Desa Kanigoro dan mitra. Tujuan pertama sosialisasi adalah membuat kesepahaman antara tim pengabdian kepada masyarakat dan peneliti dengan Pemerintah Desa Kanigoro dan mitra akan pentingnya penggalian potensi di Desa Kanigoro dan rencana kegiatan yang akan dilaksanakan. Tujuan kedua sosialisasi adalah membangun komitmen bersama dalam mengoptimalkan pengolahan ikan menjadi nugget dan abon untuk meningkatkan ekonomi keluarga dan penurunan angka kejadian stunting.

Setelah didapatkan kesepahaman antara tim pengabdian dan penelitian, pemerintah desa, dan mitra, dilaksanakan musyawarah desa yang dihadiri oleh perwakilan warga dan tokoh masyarakat. Tujuan musyawarah tersebut adalah membangun partisipasi dan mengetahui kebutuhan dasar masyarakat. Hasil musyawarah desa dijadikan dasar untuk merumuskan tindak lanjut kegiatan.

Setelah dilaksanakan musyawarah, tahapan berikutnya adalah pelatihan dan pendampingan kepada mitra. Pelatihan dan pendampingan diberikan kepada tim penggerak PKK sebagai motor penggerak sentra produksi nugget dan abon ikan. Selain itu, pelatihan juga diberikan kepada kader posyandu yang tergabung dalam Paguyuban Kader Posyandu Desa Kanigoro. Pemberdayaan sentra produksi dilaksanakan dengan tujuan untuk meningkatkan taraf perekonomian keluarga di Desa Kanigoro. Tim memberikan pelatihan kepada sentra produksi tentang strategi pemasaran langsung dan pemasaran daring. Setelah mengikuti pelatihan, diharapkan sentra produksi dapat melakukan pemasaran produk secara mandiri sehingga meningkatkan cakupan dan menjamin keberlanjutan pemasaran.

Pelatihan yang diberikan kepada kader posyandu terdiri dari 3 materi, yaitu materi terkait peningkatan kapasitas kader posyandu dalam melakukan penyuluhan pola konsumsi sehat, pemantauan stunting pada anak balita, ${ }^{7}$ dan peningkatan motivasi kader posyandu balita. Pelatihan dilakukan dengan prinsip andragogi (pendidikan orang dewasa). Setelah mengikuti pelatihan, kader posyandu diharapkan mampu melakukan pendidikan gizi dengan cara menyuluh pola konsumsi sehat dan meningkatkan konsumsi ikan pada anak balita di Desa Kanigoro. Selain itu, kader diharapkan mampu melakukan pemantauan stunting pada anak balita secara mandiri.

Kegiatan diakhiri dengan evaluasi dan pemantauan kegiatan. Pada tahap ini dilakukan evaluasi untuk mengidentifikasi faktor-faktor penghambat keberhasilan program. Evaluasi dilakukan untuk melihat kemampuan sentra produksi dalam meningkatkan mutu produk, termasuk kemasan produk. Evaluasi terhadap kader posyandu terutama dilakukan untuk melihat kemampuan kader melakukan pemantauan stunting.

Kegiatan ini telah mendapatkan izin dari Dinas Penanaman Modal Terpadu Kabupaten Gunungkidul. Surat izin juga telah ditembuskan kepada Badan Perencanaan Pembangunan Daerah Kabupaten Gunungkidul, Badan Kesatuan Bangsa dan Politik Kabupaten Gunungkidul, Camat Kecamatan Saptosari, dan Kepala Desa Kanigoro.

\section{Hasil}

Setelah melakukan sosialisasi, tim berhasil mendapatkan komitmen bersama mitra dan Pemerintah Desa Kanigoro untuk berupaya bersama-sama menggali potensi desa dengan fokus utama mengolah sumber daya ikan menjadi produk nugget dan abon. Pembuatan produk dan pengemasan dilakukan secara higienis.

Sebelum dilakukan kegiatan musyawarah desa, terlebih dahulu dilakukan identifikasi dan validasi mitra. Dari hasil identifikasi ditetapkan 
bahwa penerima manfaat kegiatan adalah ibu penggerak PKK dan kader posyandu balita. Mitra sentra produksi nugget dan abon ikan adalah ibu-ibu penggerak PKK. Kegiatan mitra dalam usaha meningkatkan status kesehatan dilakukan dengan cara penyuluhan pola konsumsi sehat dan melakukan pemantauan status stunting pada anak balita oleh kader posyandu.

Musyawarah desa dihadiri oleh ketua paguyuban kader posyandu, kepala desa, ketua penggerak PKK, dan tokoh masyarakat. Dari musyawarah desa didapatkan masukan bahwa selain keterampilan pengolahan produk nugget dan abon ikan, diperlukan juga keterampilan dalam memasarkan produk olahan tersebut. Selain itu, Desa Kanigoro juga memiliki potensi wisata alam berupa pantai, yaitu Pantai Ngrenehan, Pantai Ngobaran, dan Pantai Nguyahan. Olahan ikan berupa nugget dan abon ikan tersebut diharapkan menjadi produk khas daerah yang dapat dijadikan oleh-oleh bagi para wisatawan di Desa Kanigoro. Setelah penandatanganan kesepakatan kerjasama sebagai dasar komitmen, kegiatan bersama mitra sebagai unit sentra produksi nugget dan abon ikan dilaksanakan. Untuk meningkatkan jangkauan dan jumlah penjualan produk nugget dan abon ikan dilakukan pelatihan pengembangan produk olahan ikan (Gambar 1). Pelatihan dilaksanakan oleh tim yang terdiri dari 2 orang dosen, salah satunya mempunyai kompetensi dalam bidang ekonomi

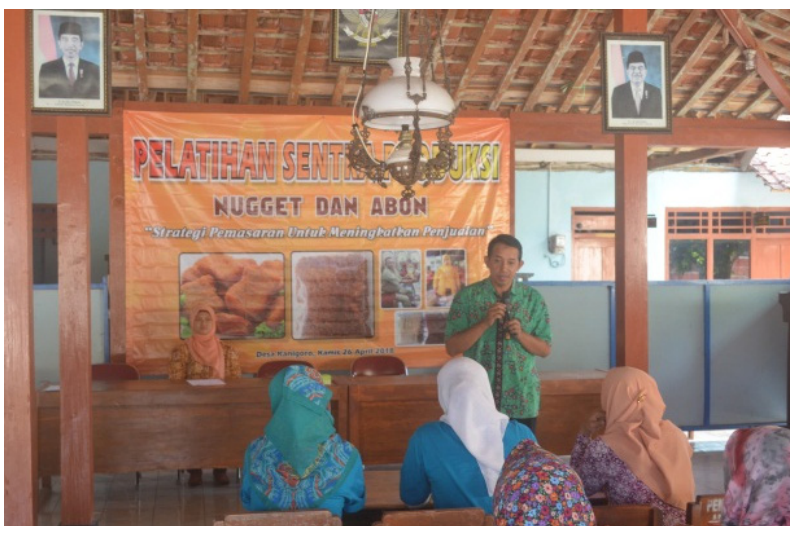

(a) dan pemasaran.

Tim dibantu oleh lima mahasiswa dari Program Studi S-1 IImu Gizi, Universitas Respati Yogyakarta, yang berperan sebagai fasilitator selama pelatihan berlangsung. Peserta yang mengikuti pelatihan pengembangan produk olahan ikan yaitu 10 orang ibu PKK dan 10 orang pemuda/ pemudi karang taruna. Materi pelatihan meliputi strategi peningkatan mutu dan strategi pemasaran.

Tim mendorong sentra produksi (tim penggerak PKK) untuk meningkatkan mutu produk yang dihasilkan. Resep nugget ${ }^{10}$ dan abon ikan ${ }^{11,12}$ diambil dari resep yang sudah tersedia, namun nugget dan abon ikan tersebut tetap perlu mandapatkan izin produksi makanan rumah tangga yang disebut izin Produk Industri Rumah Tangga (PIRT). Dengan dikeluarkannya izin tersebut, ada jaminan keamanan bagi para konsumen untuk mengkonsumsi produk.

Tim melakukan pendampingan selama proses pengemasan agar terjadi proses perbaikan terhadap mutu kemasan. Kemasan nugget dan abon ikan perlu menjadi perhatian pada saat akan melakukan pemasaran. Produk awal nugget dan abon ikan sudah dikemas, namun kurang menarik dan plastik yang digunakan belum memenuhi standar (Gambar 2a).

Dari observasi pendahuluan ditemukan bahwa produk awal nugget dan abon ikan masih belum memenuhi standar, baik dalam hal pengemasan,

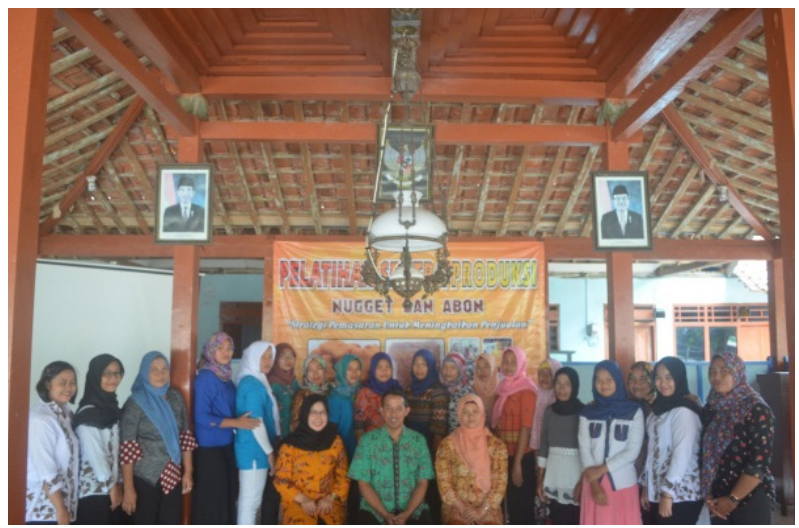

(b)

Gambar 1. Pelatihan di Desa Kanigoro. (a) Pemaparan materi pelatihan pemasaran. (b) Narasumber dan peserta pelatihan sentra produksi 


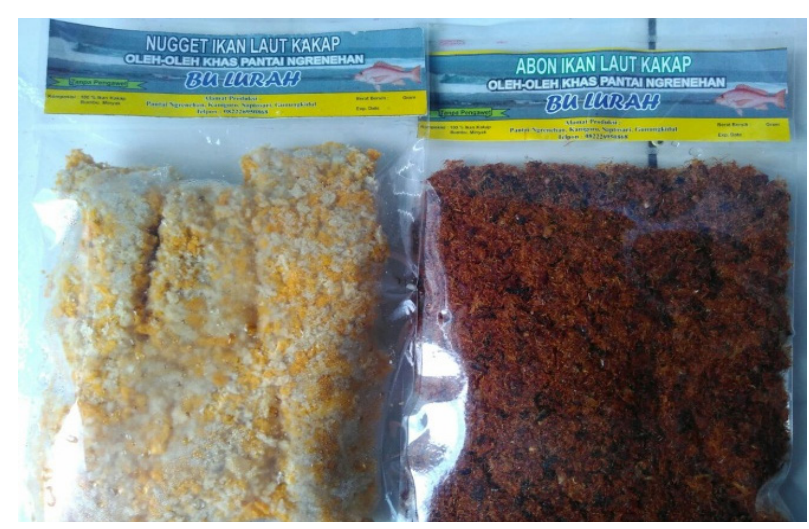

(a)

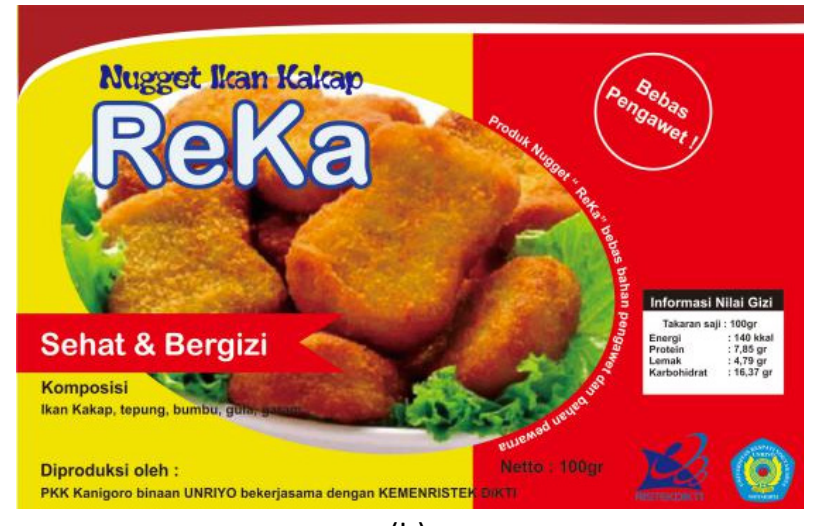

(b)

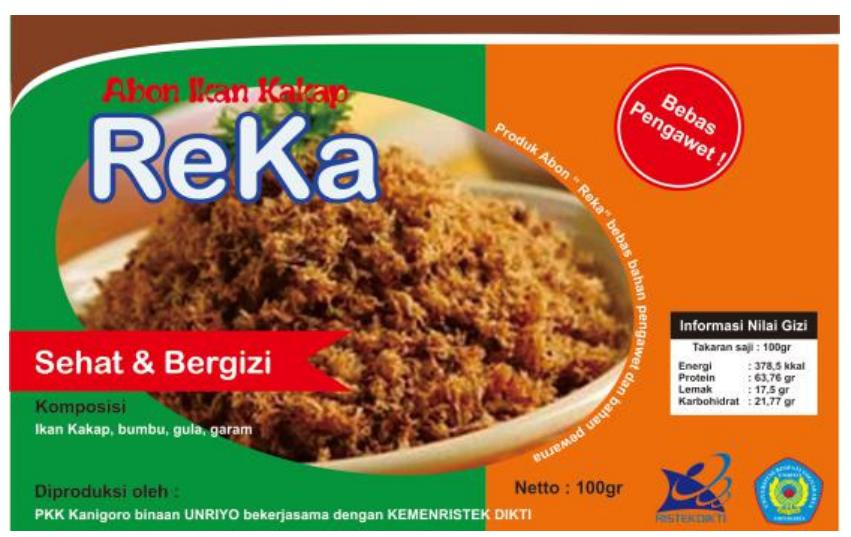

(c)

Gambar 2. Kemasan nugget dan abon ikan sebelum (a) dan sesudah (b, c) dilakukan pendampingan

rasa, keberadaan merek, penampilan, maupun standar kesehatan, sehingga daya tarik produk bagi konsumen masih rendah. Temuan tersebut ditindaklanjuti selama pendampingan sampai produk yang dihasilkan kualitasnya meningkat sesuai standar dan dapat diterima oleh kalangan yang lebih luas.

Produk beserta kemasannya juga diperhatikan dari segi kesehatan. Tim mendorong sentra produksi untuk mengujikan produk nugget dan abon ikan ke laboratorium agar kandungan gizinya diketahui. Produk nugget dan abon ikan diuji di Laboratorium Chem-Mix Pratama. Hasil analisis kandungan gizi tersebut digunakan sebagai acuan dalam mencantumkan nilai gizi pada kemasan produk.

Strategi pemasaran yang dipaparkan berupa penjelasan pemasaran langsung dan pemasaran daring. Peserta pelatihan tampak antusias dan bersemangat akan meluaskan pemasaran melalui pemasaran daring dan tanpa meninggalkan pemasaran langsung yang masih dibutuhkan. Selain pemasaran daring, sentra produksi juga didorong untuk mendistribusikan produknya ke pasaran secara langsung. Dua strategi dilakukan, antara lain menyalurkan produk ke toko grosir makanan beku dan melakukan melakukan rekrutmen pedagang kaki lima yang menjual kudapan di lingkungan sekolah untuk menjual nugget dan abon ikan ke anak sekolah secara langsung.

Pelatihan untuk kader posyandu ditujukan untuk meningkatkan kapasitas kader dalam melakukan monitoring status gizi anak balita (Gambar 3a). Tujuan diadakan pelatihan tersebut adalah agar kader mampu melaksanakan pemantauan status stunting pada anak balita di Desa Kanigoro, sehingga angka kejadian stunting pada anak balita dapat dipantau dengan baik dan diturunkan. Dalam pelatihan tersebut, kemampuan kader dalam pengukuran antropometri pada 


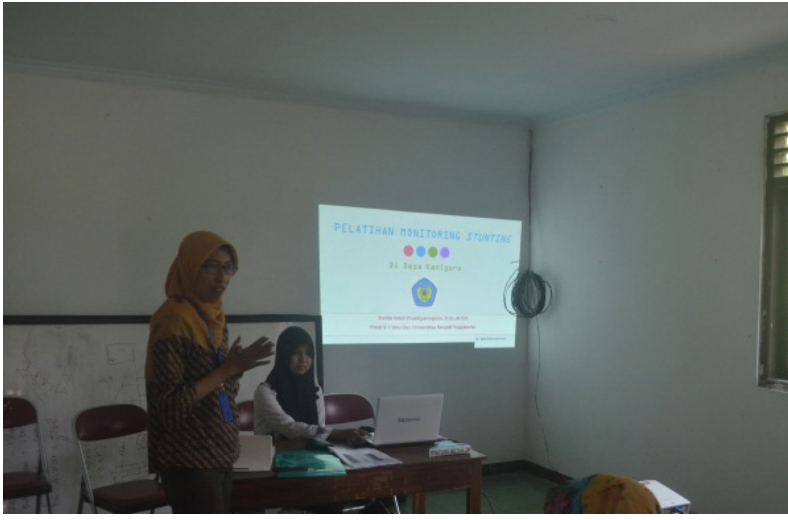

(a)

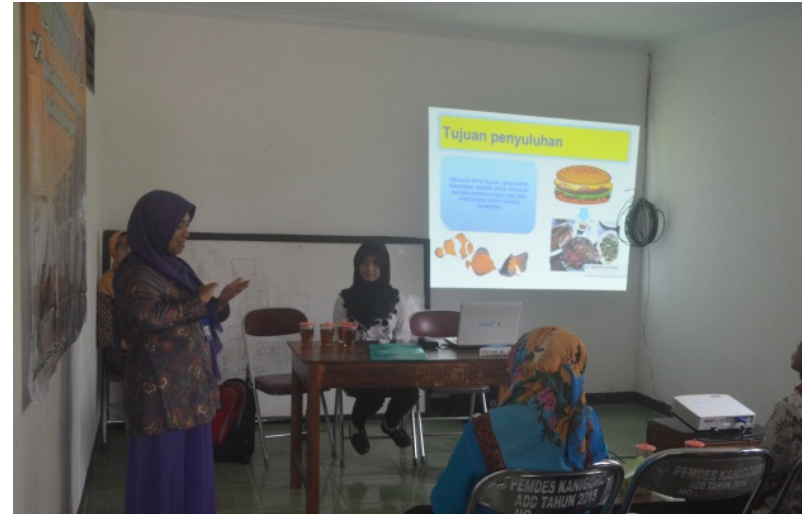

(b)

Gambar 3. Pelatihan kader posyandu. (a) Pemaparan materi pemantauan stunting. (b) Pemaparan materi penyuluhan gizi

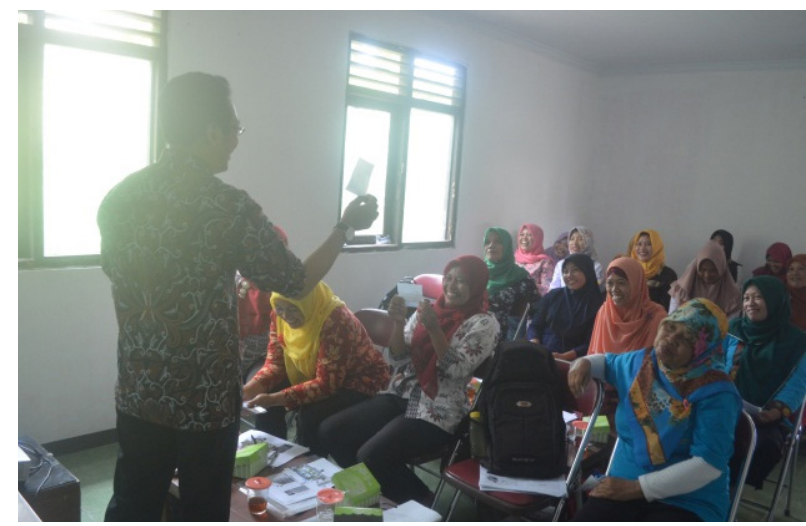

(a)

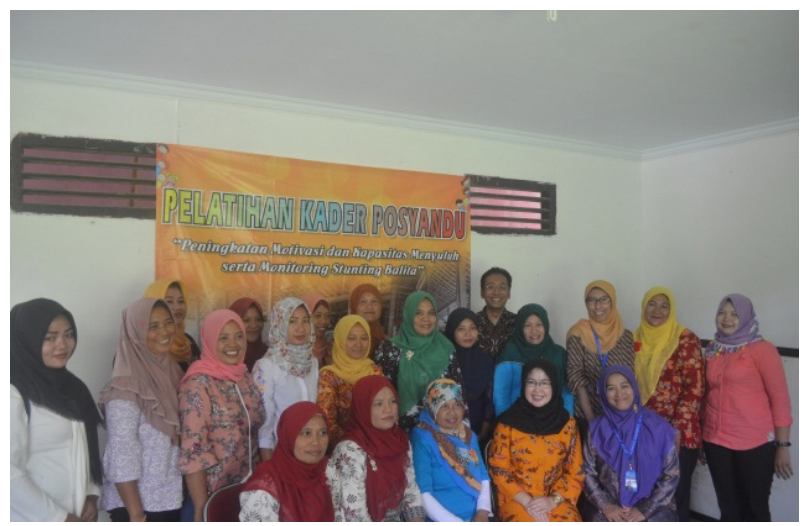

(b)

Gambar 4. Pelatihan motivasi kader posyandu. (a) Penyampaian materi. (b) Para narasumber dan peserta pelatihan

anak balita ditekankan karena presisi dan akurasi pengukuran sangat diperlukan dalam pemantauan status gizi. Presisi dan akurasi pengukuran yang dilakukan oleh kader sangat menentukan ketepatan penilaian status gizi anak balita.

Materi pelatihan yang diberikan adalah prosedur pengukuran tinggi badan anak balita, pengetahuan mengenai penentuan status gizi berdasarkan tinggi badan menurut usia ${ }^{8}$ dan perhitungan z-score untuk melakukan penilaian status gizi anak balita. Selain teori, peserta pelatihan juga diminta untuk mempraktikan pengukuran tinggi badan sehingga dapat dipastikan bahwa kader posyandu benar-benar telah mampu melakukan pengukuran tinggi badan.

Sebagai tindak lanjut dari kegiatan pelatihan tersebut, setiap bulan semua posyandu melaporkan hasil kegiatan pemantauan status gizi anak balita, tidak hanya hasil pemantauan berat badan menurut usia $(\mathrm{BB} / \mathrm{U})$, tetapi juga tinggi badan menurut usia (TB/U). ${ }^{9}$ Pada masa yang akan datang diharapkan tidak hanya dilakukan penapisan anak balita gizi kurang dan buruk saja, tetapi juga dilakukan penapisan anak balita stunting. Cakupan pengukuran TB/U anak balita menjadi $100 \%$ di Desa Kanigoro setelah dilakukan pelatihan dan hasil pengukurannya dilaporkan oleh kader.

Selain pelatihan pemantauan stunting, kader posyandu juga diberikan pelatihan dan pendampingan untuk melakukan penyuluhan gizi kepada ibu balita (Gambar 3b). Pelatihan tersebut diikuti oleh 20 orang kader. Kader diharapkan memiliki kemampuan melakukan penyuluhan untuk meningkatkan konsumsi ikan pada balita. Selanjutnya, tim memberikan pendampingan 
kepada 10 posyandu dalam melaksanakan penyuluhan pola konsumsi sehat di posyandu masing-masing setiap bulannya.

Kader posyandu memiliki peran penting dalam mengelola posyandu. Kader harus bekerja keras agar kegiatan posyandu tetap berjalan, meskipun mereka tidak bisa berharap banyak terhadap pemberian insentif sebagai balas jasa atas kerja kerasnya. Kader juga harus memiliki komitmen dan mempertahankan motivasi untuk terus mengabdi sebagai kader. Oleh karena itu, tim juga memberikan pelatihan untuk meningkatkan motivasi kader posyandu (Gambar 4).

\section{Pembahasan}

Potensi Desa Kanigoro sebagai daerah penghasil ikan dapat menjadi peluang untuk meningkatkan kesejahteraan masyarakat setempat, sekaligus menurunkan angka kejadian stunting yang tinggi. Potensi ini yang menjadi dasar tim untuk melakukan kegiatan pengabdian masyarakat di Desa Kanigoro, Saptosari, Gunungkidul dalam bentuk pengembangan industri rumahan kuliner dari bahan ikan lokal berupa nugget dan abon. Produk olahan ikan dapat dijual untuk meningkatkan status ekonomi keluarga atau dikonsumsi langsung untuk memperbaiki status gizi. Masyarakat juga perlu lebih memahami pentingnya protein dalam pencegahan stunting dan mengenal produk olahan ikan sebagai salah satu sumber protein hewani.

Kegiatan diawali dengan sosialisasi dan musyawarah desa untuk membangun kerja sama dan mengidentifikasi kebutuhan dasar masyarakat. Berbagai pemangku kepentingan turut serta dalam musyawarah desa sehingga mereka bisa memberi masukan yang sesuai dengan kebutuhan dan keadaan nyata warga. Masukan yang diterima berupa keperluan peningkatan keterampilan pemasaran produk olahan ikan dan potensi pengembangan produk olahan ikan sebagai produk khas daerah wisata. Oleh karena itu, materi pelatihan pengembangan produk difokuskan pada pemasaran produk, yaitu pemasaran daring dan pemasaran langsung melalui penyaluran produk ke toko oleh-oleh. Karena produk ditargetkan untuk dapat dijual ke wisatawan, kualitas produk juga harus ditingkatkan agar menarik minat pembeli.

Tim penggerak PKK dan kader posyandu dipilih sebagai mitra dalam kegiatan ini. Pelatihan untuk tim penggerak PKK ditekankan pada pengembangan industri produk olahan ikan, sedangkan pelatihan kader posyandu ditekankan pada pola konsumsi sehat dan pengukuran status gizi anak balita. Setelah pelatihan, kedua kelompok mitra mempraktikkan apa yang sudah diajarkan dengan pendampingan dari tim.

Sejumlah 10 orang ibu PKK dan 10 orang pemuda/ pemudi karang taruna mengikuti pelatihan strategi pemasaran dan peningkatan mutu produk. Para peserta pelatihan diharapkan dapat menularkan ilmu yang diperoleh kepada warga yang lain agar keberlangsungan program dapat terjamin. Pemasaran daring yang diperkenalkan ternyata merupakan ide baru bagi peserta. Di era revolusi industri 4.0 saat ini, pembelian daring lebih banyak diminati sehingga dapat menjadi peluang perluasan pasar yang baik. Pemasaran produk nugget dan abon ikan yang semakin baik akan mendorong peningkatan produksi yang berujung pada peningkatan kesejahteraan masyarakat Desa Kanigoro.

Peningkatan mutu produk dilakukan dengan pengurusan izin Produk Industri Rumah Tangga (PIRT), perbaikan kemasan, dan penambahan informasi kandungan gizi produk. Penjualan produk industri rumah tangga perlu memperhatikan cara produksi pangan yang baik (CPPB) dan memiliki izin PIRT. Tim penggerak PKK sebelumnya telah mendapatkan pelatihan dari dinas kesehatan mengenai CPPB, yang meliputi keamanan pangan dan manajemen usaha produksi. Namun ijin resmi PIRT tetap dibutuhkan sebagai jaminan bagi konsumen terkait keamanan produk yang akan dipasarkan yakni nugget dan abon ikan.

Dengan pelatihan dan pendampingan, kualitas kemasan nugget dan abon ikan dapat ditingkatkan sehingga lebih rapi, higienis, dan menarik. Informasi kandungan gizi produk juga sudah diketahui sehingga bisa dicantumkan di kemasan (Gambar $2 \mathrm{~b}$ dan $2 \mathrm{c}$ ). Dengan pengemasan yang higienis dan 
menarik, produk nugget dan abon ikan menjadi layak untuk dijual sebagai oleh-oleh khas dari Desa Kanigoro dan diminati oleh para wisatawan yang datang ke daerah wisata pantai setempat.

Upaya peningkatan pengetahuan masyarakat mengenai pentingnya protein dalam mencegah stunting juga dilakukan dalam bentuk penyuluhan. Sejumlah 20 kader posyandu dilatih untuk memberikan penyuluhan gizi pada ibu balita. Jumlah kader tersebut dirasakan sudah ideal karena setelah pelatihan juga dilakukan pendampingan terhadap kader. Jumlah peserta yang tidak terlalu banyak menjamin efektivitas pelatihan dan pendampingan. Setelah pelatihan, kader telah mampu memberikan penyuluhan pola konsumsi sehat di 10 posyandu. Kader-kader terlatih ini diharapkan dapat membagikan pengetahuan dan pengalamannya kepada kader yang lain yang tidak mengikuti pelatihan sehingga keberlanjutan program lebih terjamin.

Kader posyandu juga dilatih untuk melakukan penapisan dan pemantauan stunting pada anak balita. Pelatihan dilakukan baik dalam bentuk teori maupun praktik langsung pengukuran tinggi badan anak. Pengukuran tinggi badan dibutuhkan untuk mendeteksi kasus baru maupun memantau kasus stunting pada anak balita. Presisi dan akurasi pengukuran yang dilakukan oleh kader sangat menentukan ketepatan penilaian status gizi anak balita.

Setelah menerima pelatihan, semua kader posyandu di Desa Kanigoro melaporkan hasil kegiatan pemantauan status gizi anak balita, tidak hanya hasil pemantauan berat badan menurut usia $(\mathrm{BB} / \mathrm{U})$, tetapi juga tinggi badan menurut usia (TB/U). Pada masa yang akan datang diharapkan tidak hanya dilakukan penapisan anak balita gizi kurang dan buruk saja, tetapi juga dilakukan penapisan anak balita stunting, yang juga termasuk dalam pemeriksaan status gizi sesuai standar World Health Organization (WHO). ${ }^{9}$ Cakupan pengukuran TB/U anak balita menjadi $100 \%$ di Desa Kanigoro setelah dilakukan pelatihan dan hasil pengukurannya dilaporkan oleh kader. Dengan seluruh pelatihan yang dilaksanakan ini, diharapkan angka kejadian stunting dapat terus dipantau dan akhirnya menurun.

\section{Kesimpulan}

Dengan kegiatan yang dijalankan, telah terjadi peningkatan pemahaman dan keterampilan membuat nugget dan abon ikan dengan mutu yang lebih baik dari segirasa, standar kesehatan, kemasan, dan keberadaan merek. Terjadi peningkatan pemahaman, keterampilan, dan partisipasi kader posyandu dalam melakukan pemantauan stunting dan penyuluhan pola konsumsi sehat. Kegiatan pemantauan stunting di posyandu dan penyuluhan mengenai pola konsumsi ikan dapat terlaksana dengan baik. Kader posyandu dapat membuat laporan hasil penapisan kejadian stunting dari seluruh populasi balita di Desa Kanigoro. Apabila kegiatan pemantauan stunting anak balita oleh kader dapat berjalan rutin dan berkelanjutan maka akan memperkuat surveilans gizi di Desa Kanigoro.

\section{Ucapan terima kasih}

Kegiatan pengabdian kepada masyarakat dan penelitian ini dibiayai oleh Hibah Pogram Kemitraan Masyarakat (PKM) dari Kementerian Riset, Teknologi, dan Pendidikan Tinggi Republik Indonesia , tahun anggaran 2018.

\section{Daftar pustaka}

1. Pemerintahan Desa Kanigoro. Profil Desa Kanigoro. Desa Kanigoro: Pemerintahan Desa Kanigoro; 2017.

2. Syafiq A, Setiarini A, Utari DM, Achadi EL, Fatmah K, Sartika RAD, et al. Gizi dan kesehatan masyarakat. Jakarta: PT Raja Grafindo Persada; 2010.

3. Ngaisyah D, Wahyuni S. Resiko terjadinya kegemukan dan keterlambatan perkembangan pada balita usia 2-5 tahun dengan stunting di Desa Kanigoro, Saptosari, Gunungkidul, Yogyakarta. Yogyakarta: Universitas Respati Yogyakarta; 2017.

4. Kementerian Kesehatan Republik Indonesia. Riset kesehatan dasar 2013. Jakarta: Badan 
Penelitian dan Pengembangan Kesehatan Kementerian Kesehatan Republik Indonesia; 2013. 306 p.

5. Kementerian Desa, Pembangunan Daerah Tertinggal, dan Transmigrasi RepublikIndonesia. Buku saku desa dalam penanganan stunting. Jakarta: Kementerian Desa, Pembangunan Daerah Tertinggal, dan Transmigrasi Republik Indonesia; 2017.

6. Kementerian Kesehatan Republik Indonesia. Buku saku posyandu. Jakarta: Pusat Promosi Kesehatan Kementerian Kesehatan Republik Indonesia; 2012.

7. Supariasa IDN, Bakri B, Fajar I. Penilaian status gizi. Jakarta: EGC; 2002.

8. Kementerian Kesehatan Republik Indonesia. Riset kesehatan dasar 2010. Jakarta: Badan
Penelitian dan Pengembangan Kesehatan Kementerian Kesehatan Republik Indonesia; 2010.

9. World Health Organization. WHO child growth standards based on length/ height, weight and age. Acta Pædiatr. 2006;Suppl 450:76-85.

10. Marni OWN. Pembuatan nugget ikan. 2010. Available from: http://kamiitp08.blogspot. co.id/2010/10/pembuatannughetikan.html.

11. Angwar M, Rahayu E. Modul pelatihan pembuatan abon ikan lele untuk UKM. Jakarta: LIPI Press; 2016.

12. Pembuatan abon ikan. 2013. Available from: http://terapanteknologitepatguna.blogspot. co.id/2013/06/proses-pembuatan-abon-ikan. html 